\title{
Hepatic insulin resistance and increased hepatic glucose production in mice lacking Fgf21
}

\author{
João Paulo G Camporez ${ }^{1}$, Mohamed Asrih ${ }^{3}$, Dongyan Zhang ${ }^{1,2}$, Mario Kahn ${ }^{1,2}$, \\ Varman T Samuel ${ }^{1}$, Michael J Jurczak ${ }^{1,2}$ and François R Jornayvaz, ${ }^{1,3}$ \\ ${ }^{1}$ Department of Internal Medicine and ${ }^{2}$ Howard Hughes Medical Institute, Yale University School of Medicine, \\ New Haven, Connecticut 06536, USA \\ ${ }^{3}$ Service of Endocrinology, Diabetes and Metabolism, Lausanne University Hospital, Rue du Bugnon 46, \\ 1011 Lausanne CHUV, Switzerland
}

\author{
Correspondence \\ should be addressed \\ to F R Jornayvaz \\ Email \\ francois.jornayvaz@chuv.ch
}

\begin{abstract}
Fibroblast growth factor 21 (FGF21) is an important regulator of hepatic glucose and lipid metabolism and represents a potential pharmacological agent for the treatment of type 2 diabetes and obesity. Mice fed a ketogenic diet (KD) develop hepatic insulin resistance in association with high levels of FGF21, suggesting a state of FGF21 resistance. To address the role of FGF21 in hepatic insulin resistance, we assessed insulin action in FGF21 whole-body knock-out (FGF21 KO) male mice and their littermate WT controls fed a KD. Here, we report that FGF21 KO mice have hepatic insulin resistance and increased hepatic glucose production associated with an increase in plasma glucagon levels. FGF21 KO mice are also hypometabolic and display increased fat mass compared with their WT littermates. Taken together, these findings support a major role of FGF21 in regulating energy expenditure and hepatic glucose and lipid metabolism, and its potential role as a candidate

in the treatment of diseases associated with insulin resistance.
\end{abstract}

\author{
Key Words \\ - FGF21 \\ - insulin resistance \\ - NAFLD \\ - energy expenditure \\ - obesity
}

Journal of Endocrinology (2015) 226, 207-217

\section{Introduction}

The prevalence of obesity has dramatically risen over the last few decades and is not only affecting adults, but also children and adolescents (Finucane et al. 2011). Based on the National Health and Nutrition Examination Survey (NHANES), it is estimated that more than $34 \%$ of adults are obese and $68 \%$ are overweight or obese (Flegal et al. 2010). In parallel with obesity, nonalcoholic fatty liver disease (NAFLD), which is now the most prevalent chronic liver disease in the USA, is affecting about one out of three individuals (Williams et al. 2011). NAFLD is a major risk factor in the development of insulin resistance and type 2 diabetes (Angulo 2002, Fabbrini et al. 2010, Asrih \& Jornayvaz 2015).
() 2015 Society for Endocrinology Printed in Great Britain
Fibroblast growth factor 21 (FGF21) is an important regulator of glucose metabolism (Kharitonenkov et al. 2005). FGF21 levels are increased in NAFLD and correlate with hepatic triglyceride content (Li et al. 2010); therefore, FGF21 is considered an emergent biomarker of NAFLD (Dushay et al. 2010, Morris-Stiff \& Feldstein 2010). In dietinduced obese mice, which have already increased levels of FGF21, suggesting a state of FGF21 resistance, chronic administration of FGF21 reverses hepatic steatosis and improves insulin sensitivity (Xu et al. 2009, Camporez et al. 2013). Mice lacking Fgf21 (FGF21 knock-out (KO)) gain weight in an age-dependent manner, with an increase in both fat and lean mass, and develop glucose intolerance

Published by Bioscientifica Ltd. 
on regular chow when assessed by intraperitoneal glucose tolerance tests (Badman et al. 2009). When fed a ketogenic diet (KD), FGF21 KO mice gain weight, develop NAFLD and impaired glucose control (Badman et al. 2009), although these findings have been questioned (Murata et al. 2013). Also, mice specifically lacking $F g f 21$ in the liver fed a high-fat diet have recently been shown to develop significant hepatic steatosis and insulin resistance when assessed by an insulin tolerance test (Markan et al. 2014).

We previously showed that WT mice fed a KD develop hepatic insulin resistance despite gaining less weight than mice fed regular chow. In this case, hepatic insulin resistance was secondary to the accumulation of diacylgycerols (DAG), which are lipid intermediates known to activate protein kinase $\mathrm{C}$ epsilon (PKCE), which subsequently impairs insulin signaling (Samuel et al. 2007). Lower body weight in mice fed a KD was secondary to higher energy expenditure, which was attributed to an increase in FGF21 plasma concentrations, as caloric intake and locomotor activity were similar (Jornayvaz et al. 2010). We therefore hypothesized that FGF21 KO mice would have lower energy expenditure and develop more hepatic insulin resistance compared to WT mice when fed a KD. In order to examine this hypothesis, we assessed whole-body glucose turnover in awake mice using the hyperinsulinemic-euglycemic clamp technique combined with radiolabeled glucose, and energy expenditure by indirect calorimetry. In addition, we assessed liver lipid intermediates that have been associated with insulin resistance, such as triglycerides, DAG, and ceramides (Shulman 2000, Holland et al. 2007, Samuel et al. 2010, Jornayvaz \& Shulman 2012), as well as signaling events typically associated with an increase in liver DAG content. Finally, given the well-established associations between endoplasmic reticulum (ER) stress and inflammation with insulin resistance (Ozcan et al. 2004, Hotamisligil 2006, 2010), we also assessed these pathways in FGF21 KO mice.

\section{Materials and methods}

\section{Animals}

Male FGF21 KO mice and WT littermates were generated as previously described (Potthoff et al. 2009) and individually housed under controlled temperature $\left(23^{\circ} \mathrm{C}\right)$ and lighting ( $12 \mathrm{~h}$ light:12 $\mathrm{h}$ darkness cycle, lights on at $0700 \mathrm{~h}$ ) with free access to water and food. One week after arrival in the animal care facility, a KD (F3666, Bio-Serv, Frenchtown, NJ, USA) was started and continued for 5 weeks. The proportions of calories derived from nutrients were as follows: $95.1 \%$ fat, $0.4 \%$ carbohydrate, $4.5 \%$ protein, and energy density $7.456 \mathrm{kcal} / \mathrm{g}$. Body composition was assessed by ${ }^{1} \mathrm{H}$ magnetic resonance spectroscopy using a Bruker Minispec Analyzer (Bruker BioSpin, Billerica, MA, USA). Energy expenditure, RQ, $\mathrm{VO}_{2}, \mathrm{VCO}_{2}$, locomotor activity, and food intake were measured using a Comprehensive Lab Animal Metabolic System (CLAMS; Colombus Instruments, Columbus, OH, USA). Drinking was measured as previously described (Birkenfeld et al. 2011). Mice were $\sim 3$ months old during the experiments. All experiments were done in 6-h fasted animals. All procedures were approved by the Yale University Animal Care and Use Committee.

\section{Plasma assays}

Blood samples were collected by cardiac puncture in heparinized syringes and centrifuged at $10,000 \boldsymbol{g}$ for 2 min. Plasma was then either directly used or frozen at $-20^{\circ} \mathrm{C}$ for further analyzes. Plasma glucose $(10 \mu \mathrm{l} /$ sample $)$ was measured using a YSI 2700D glucose analyzer (YSI, Inc., Yellow Springs, OH, USA). Plasma fatty acids were determined with the NEFA C Kit (Wako Pure Chemical Industries, Osaka, Japan). Plasma insulin, glucagon, and adiponectin were measured by RIA Kits (Millipore, Billerica, MA, USA). For glucagon measurements, aprotinin was added to the blood during collection to avoid degradation. Cholesterol panel was analyzed using COBAS Mira Plus (Roche). Plasma cytokines were measured using a mouse multiplex assay kit (Meso Scale Discovery, Gaithersburg, MD, USA).

\section{Liver lipid intermediates measurements}

Tissue triglycerides were extracted using the method of Bligh \& Dyer (1959) and measured using a commercial triglyceride reagent (Diagnostic Chemicals Limited, Oxford, CT, USA). Cytosolic DAG were measured as previously described ( $\mathrm{Yu}$ et al. 2002, Jornayvaz et al. 2011). Total DAG contents are expressed as the sum of individual species. Ceramides content was measured as previously described (Yu et al. 2002).

\section{Hepatic glycogen measurements}

Frozen livers were homogenized in perchloric acid. Glucose concentration was measured (YSI 2700D glucose analyzer; YSI, Inc.) in the raw homogenates and in hydrolyzed homogenates after the addition of

Published by Bioscientifica Ltd 
amyloglucosidase from Aspergillus niger (Sigma-Aldrich). Results are expressed as $\mathrm{mg}$ of glycogen per $100 \mathrm{mg}$ of tissue.

\section{Hyperinsulinemic-euglycemic clamp studies}

Jugular venous catheters were implanted 6-7 days prior to the hyperinsulinemic-euglycemic clamp experiments. Hyperinsulinemic-euglycemic clamps were conducted as previously described (Jornayvaz et al. 2011). Briefly, after overnight fasting, restrained mice were infused with $\left[3-{ }^{3} \mathrm{H}\right]$-glucose at a rate of $0.05 \mu \mathrm{Ci} / \mathrm{min}$ for $120 \mathrm{~min}$ to measure basal glucose turnover. After the basal period, hyperinsulinemic-euglycemic clamp was performed for 120 min with a 4 -min primed insulin $(20 \mathrm{mU} / \mathrm{kg})$ followed by a continuous infusion $(3 \mathrm{mU} / \mathrm{kg}$ per $\mathrm{min})$. $\left[3-{ }^{3} \mathrm{H}\right]$-glucose was infused at a rate of $0.1 \mu \mathrm{Ci} / \mathrm{min}$ and $20 \%$ dextrose was infused in variable rates to maintain euglycemia $(\sim 120 \mathrm{mg} / \mathrm{dl}) .10 \mu \mathrm{Ci}$ bolus of 2-deoxyD- $\left[1-{ }^{14}\right.$ C]glucose (Perkin Elmer Life Sciences, Boston, MA, USA) was injected after $85 \mathrm{~min}$ to estimate the insulinstimulated tissue glucose uptake. Blood samples were collected by tail bleeding (at $0,25,50,65,80,90,100$, 110 , and $120 \mathrm{~min}$ ). Clamps were performed according to standard operating procedures (Ayala et al. 2010). At the end of the clamp, mice were anesthetized with pentobarbital sodium injection $(150 \mathrm{mg} / \mathrm{kg})$ and all tissues were taken within $4 \mathrm{~min}$, snap-frozen in liquid nitrogen using aluminum tongs and stored at $-80^{\circ} \mathrm{C}$ for subsequent analysis. Biochemical analysis and calculations for the hyperinsulinemic-euglycemic clamps were performed as previously described (Jornayvaz et al. 2011).

\section{Liver insulin signalling}

PKC $\varepsilon$ membrane activation was assessed in liver protein extracts as previously described (Choi et al. 2007).

\section{Immunoblot analysis}

Immunoblots were done as previously described (Jornayvaz et al. 2012). Membranes were incubated overnight with primary antibodies for phospho-Akt2 $\left(\mathrm{Ser}^{474}\right)$ (Cell Signaling Technology, Danvers, MA, USA), phosphoenolpyruvate carboxykinase (PEPCK; Abcam, Cambride, MA, USA), pyruvate carboxylase (PC; Abcam), uncoupling protein 1 (UCP1; Santa Cruz Biotechnology), C/EBP homologous protein (CHOP; Cell Signaling Technology), IgH chain binding protein (BIP; Cell Signaling Technology), phospho-eIF2 $\alpha$ (Cell Signaling Technology), or
phospho-JNK (Cell Signaling Technology). After further washings, membranes were incubated with HRP-conjugated secondary antibody (Bio-Rad) and visualized by ECL substrate (Pierce, Rockford, IL, USA). Membranes were stripped and reblotted with anti-total Akt antibody (Cell Signaling Technology), total eIF2 $\alpha$ (Cell Signaling Technology), total JNK (Cell Signaling Technology), or glyceraldehyde-3-phosphate dehydrogenase (Santa Cruz Biotechnology). Bands were then quantified using Image J (National Institutes of Health, Bethesda, MD, USA).

\section{Total RNA preparation, real-time quantitative PCR analysis}

Total RNA was extracted from frozen livers using RNeasy 96-Kit (Qiagen). Then, $1 \mu \mathrm{g}$ of RNA was reverse-transcribed into cDNA with the use of the Quantitect RT Kit (Qiagen) as per manufacturer's protocol. The abundance of transcripts was assessed by real-time PCR on a 7500 Real-Time PCR System (Applied Biosystems) with a SYBR Green detection system. Samples were run in duplicate for both the gene of interest and cyclophilin, and data were normalized for the efficiency of amplification according to Pfaffl's equation (Pfaffl 2001), as determined by a standard curve included on each run. Primers used are available upon request.

\section{Statistical analysis}

Data are expressed as means \pm s.E.M. Results were assessed using two-tailed unpaired Student's $t$-test or one-way ANOVA (GraphPad Prism 5, La Jolla, CA, USA). A $P$ value $<0.05$ was considered significant.

\section{Results}

\section{Decreased energy expenditure in FGF21 KO mice}

Body weights of FGF21 KO mice studied at $\sim 3$ months of age were not significantly different than their WT littermate controls. Body fat expressed as a percentage of body weight was $\sim 40 \%$ higher in FGF21 KO mice and there was no difference in their percent lean mass compared to controls (Table 1). However, when expressed in grams, lean mass was significantly lower in FGF21 KO mice (Table 1). $\mathrm{VO}_{2}$ (Fig. 1A) and $\mathrm{VCO}_{2}$ (Fig. 1B) were $\sim 15 \%$ lower and energy expenditure was $\sim 10 \%$ lower (Fig. 1C) in FGF21 KO mice than WT mice. Importantly, locomotor activity and caloric intake were similar between genotypes, as were respiratory quotient and drinking (Table 1). In accordance with the decrease in energy

Published by Bioscientifica Ltd 
Table 1 Physiologic parameters and plasma analyses. Data are represented as mean \pm s.E.M.

\begin{tabular}{|c|c|c|}
\hline & WT & FGF21 KO \\
\hline \multicolumn{3}{|l|}{ Physiological parameters } \\
\hline Body weight (g) & $23.1 \pm 0.6$ & $21.2 \pm 0.7$ \\
\hline Fat mass $(\mathrm{g})$ & $2.0 \pm 0.1$ & $2.6 \pm 0.3$ \\
\hline Lean mass (g) & $16.9 \pm 0.5$ & $15.1 \pm 0.4^{*}$ \\
\hline Fat mass ( $\%$ of body weight) & $8.8 \pm 0.5$ & $12.0 \pm 0.3^{*}$ \\
\hline Lean mass ( $\%$ of body weight) & $73.2 \pm 0.6$ & $71.6 \pm 1.1$ \\
\hline $\begin{array}{l}\text { Caloric intake per mouse } \\
(\mathrm{kcal} /(\text { mouse- } \mathrm{h}))\end{array}$ & $0.57 \pm 0.06$ & $0.49 \pm 0.06$ \\
\hline RQ & $0.73 \pm 0.00$ & $0.73 \pm 0.00$ \\
\hline Drinking (ml/(mouse-h)) & $0.01 \pm 0.00$ & $0.01+0.00$ \\
\hline Activity (counts/h) & $65.6 \pm 10.8$ & $80.9 \pm 13.8$ \\
\hline \multicolumn{3}{|l|}{ Plasma analyses } \\
\hline Fasting insulin $(\mu \mathrm{U} / \mathrm{ml})$ & $9.9 \pm 1.7$ & $15.4 \pm 4.6^{*}$ \\
\hline Clamp insulin $(\mu \mathrm{U} / \mathrm{ml})$ & $61.3 \pm 12.2$ & $73.1 \pm 8.3$ \\
\hline Fasting glucagon (pg/ml) & $118.7 \pm 38.6$ & $245.1 \pm 23.0 *$ \\
\hline Fasting FA (mmol/l) & $1.3 \pm 0.2$ & $1.7 \pm 0.4^{*}$ \\
\hline Insulin-stimulated FA (mmol/l) & $0.5 \pm 0.1$ & $0.8 \pm 0.2^{*}$ \\
\hline Insulin suppression of FA (\%) & $63.0 \pm 5.5$ & $54.4 \pm 6.8^{*}$ \\
\hline Total cholesterol (mg/dl) & $181.6+20.2$ & $291.7 \pm 20.3^{\dagger}$ \\
\hline HDL cholesterol (mg/dl) & $94.0 \pm 4.3$ & $98.8 \pm 2.4$ \\
\hline Triglycerides (mg/dl) & $57.7 \pm 6.7$ & $83.1 \pm 17.3$ \\
\hline Adiponectin $(\mu \mathrm{g} / \mathrm{ml})$ & $9.8 \pm 1.1$ & $10.4 \pm 0.6$ \\
\hline Interleukin 1 beta (pg/ml) & $1.6 \pm 0.7$ & $5.8 \pm 1.5^{\ddagger}$ \\
\hline Interferon gamma (pg/ml) & $1.0 \pm 0.2$ & $1.1 \pm 0.1$ \\
\hline Interleukin 6 (pg/ml) & $6.6 \pm 0.7$ & $8.2 \pm 2.3$ \\
\hline Interleukin $10(\mathrm{pg} / \mathrm{ml})$ & $43.2 \pm 1.6$ & $50.3 \pm 3.4$ \\
\hline $\begin{array}{l}\text { Tumor necrosis factor alpha } \\
(\mathrm{pg} / \mathrm{ml})\end{array}$ & $5.9 \pm 0.5$ & $6.4 \pm 0.5$ \\
\hline
\end{tabular}

$\mathrm{RQ}$, respiratory quotient; FA, fatty acids. $n=4-12$ mice/group. ${ }^{*} P<0.05$ and ${ }^{\dagger} P<0.01$ vs WT. ${ }^{\ddagger} P=0.08$ vs WT.

expenditure, we found that protein levels of UCP1 in brown adipose, which is the main protein dissipating heat in the brown adipose tissue, was significantly reduced in FGF21 KO mice (Fig. 1D), corroborating the role of FGF21 in inducing UCP1 gene expression in brown adipose tissue (Fisher et al. 2012). Finally, basal plasma analyses revealed an $\sim 60 \%$ increase in total cholesterol in FGF21 KO, whereas there was no difference in HDL cholesterol and triglycerides (Table 1), suggesting a role for FGF21 in cholesterol metabolism.

\section{Hepatic insulin resistance in FGF21 KO mice}

We performed hyperinsulinemic-euglycemic clamps to assess hepatic and peripheral insulin sensitivity. Glucose infusion rates required to maintain euglycemia (Fig. 2A) during the clamps were $\sim 30 \%$ lower in FGF21 KO mice compared to WT mice, demonstrating whole-body insulin resistance in FGF21 KO mice (Fig. 2B). Basal endogenous glucose production was $\sim 20 \%$ higher in FGF21 KO mice (Fig. 2C) without any difference in basal plasma glucose, whereas the suppression of endogenous glucose production by insulin during the clamp was $\sim 60 \%$ lower in FGF21 KO mice (Fig. 2D), reflecting severe hepatic insulin resistance. However, insulin-stimulated whole-body glucose disposal (Fig. 2E) was similar between genotypes, demonstrating that the differences in whole-body glucose turnover were due specifically to hepatic insulin resistance in FGF21 KO mice. Basal plasma fatty acid concentrations were $\sim 30 \%$ higher in FGF21 KO mice and the ability of insulin to suppress plasma fatty acid concentrations during the hyperinsulinemic-euglycemic clamps was also significantly decreased in FGF21 KO mice (Table 1), suggesting that insulin suppression of white adipose tissue lipolysis was also impaired in these mice. Fasting plasma insulin concentrations were $\sim 55 \%$ higher in FGF21 KO mice, whereas insulin concentrations during
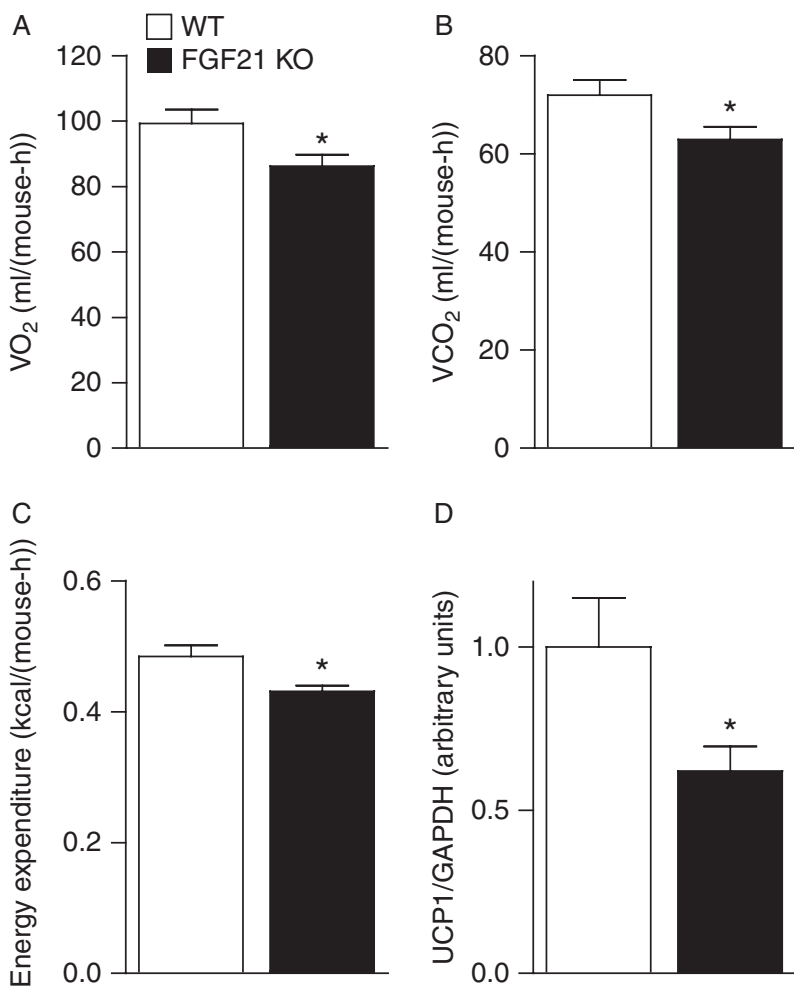

D
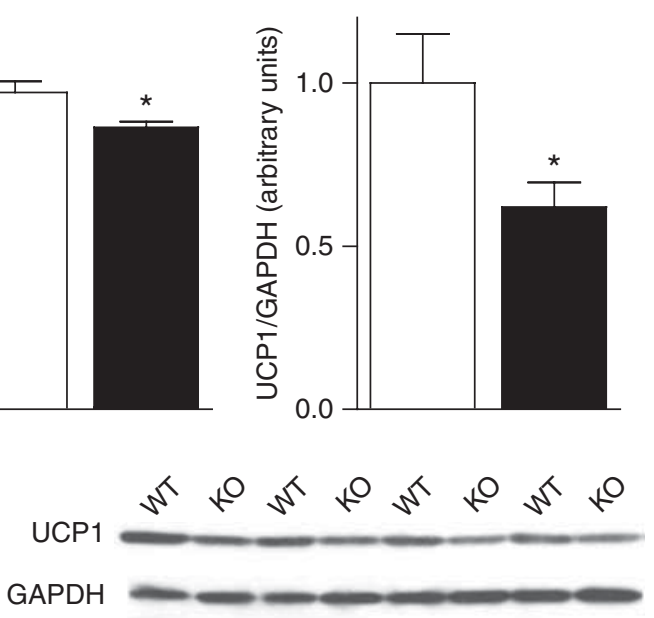

Figure 1

Decreased energy expenditure in FGF21 $\mathrm{KO}$ mice. $\mathrm{VO}_{2}(\mathrm{~A}), \mathrm{VCO}_{2}(\mathrm{~B})$, and energy expenditure per mouse (C) were significantly lower in FGF21 KO mice ( $n=10-12 /$ group). Accordingly, the protein level of UCP1 (D) was significantly decreased in FGF21 KO mice ( $n=4-5 /$ group). ${ }^{*} P<0.05$ vs WT mice. Data are represented as mean \pm s.E.M.

Published by Bioscientifica Ltd. 

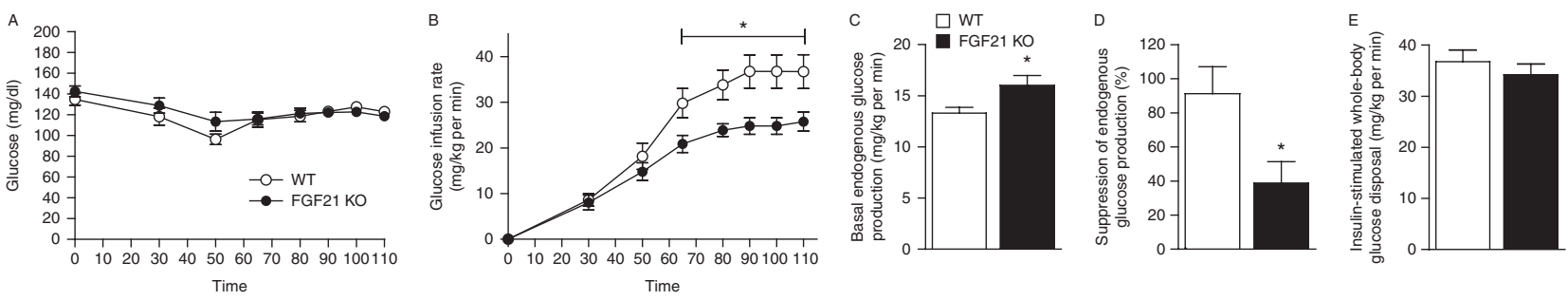

Figure 2

Hepatic insulin resistance in FGF21 KO mice. (A) Glucose was maintained around $100-120 \mathrm{mg} / \mathrm{dl}$ during the hyperinsulinemic-euglycemic clamps. Glucose infusion rates (B) were significantly lower in FGF21 KO mice compared to their WT littermate controls. Basal endogenous glucose production (C) was higher in FGF21 KO mice. FGF21 KO mice displayed

the clamp were similar between genotypes (Table 1), which is important to allow clamp data comparisons between groups.

To assess the role of FGF21 deficiency in insulin resistance in vitro, we measured FGF21 expression in HepG2 cells in basal conditions and found that it was very low (data not shown), suggesting that knocking down FGF21 would have little effect in these cells. These findings are in line with previous studies in different hepatic cell lines (Potthoff et al. 2009, Wang et al. 2010, Schaap et al. 2013) and overall suggest that the role of FGF21 in insulin resistance is more relevant in in vivo systems.

\section{NAFLD and impaired hepatic insulin signaling in FGF21 KO mice}

FGF21 KO mice, like WT mice, develop NAFLD when fed a KD. However, liver lipid intermediates, triglycerides (Fig. 3A), cytosolic DAG (Fig. 3B), and ceramides (Fig. 3C) were all significantly higher in FGF21 KO mice. The increase in hepatic DAG content was associated with a significant increase in $\mathrm{PKC} \varepsilon$ membrane translocation (Fig. 3D) and a subsequent $\sim 10 \%$ decrease in phosphoAkt2 phosphorylation (Fig. 3E), confirming hepatic insulin resistance in FGF21 KO mice downstream of the insulin receptor.

The interaction of FGF21 with $\beta$-klotho is necessary for its biological action (Kharitonenkov \& Larsen 2011, Ding et al. 2012). We therefore assessed part of FGF21 signaling in the liver. Interestingly, although mice fed a KD are known to display altered FGF21 signaling compared to mice fed regular chow (Asrih et al. 2015), we found no difference in $\beta$-klotho (Supplementary Figure $1 \mathrm{~A}$, see section on supplementary data given at the end of this article), FGF receptor 1 (Supplementary hepatic insulin resistance as reflected by the inability of insulin to suppress endogenous glucose production during the hyperinsulinemic-euglycemic clamps (D). Insulin-stimulated whole-body glucose disposal (E) was similar between groups ( $n=9-10 /$ group). ${ }^{\star} P<0.05$ vs WT mice. Data are represented as mean \pm S.E.M.

Figure 1B), and 4 (Supplementary Figure 1C) hepatic mRNA expression.

\section{ER stress and inflammation in FGF21 KO mice}

ER stress and inflammation are also considered as alternative hypotheses to explain hepatic insulin resistance (Ozcan et al. 2004, Hotamisligil 2006, Asrih \& Jornayvaz 2013). We therefore examined several markers of these pathways. Hepatic protein levels of CHOP (Fig. 4A), BIP (Fig. 4B), two important markers of ER stress, were similar between groups. However, phospho-eIF $2 \alpha$, another ER stress marker, was increased by $\sim 35 \%$ in FGF21 KO mice (Fig. 4C). Protein levels of phospho-JNK, an important marker of inflammation, were similar between groups (Fig. 4D). Additionally, concentrations of plasma cytokines, namely interleukin 6 (IL6), interferon gamma, IL10, and tumor necrosis factor alpha were not different between FGF21 KO and WT mice (Table 1). However, IL1 $\beta$ tended to be higher in FGF21 KO mice $(P=0.08$; Table 1$)$. Finally, adiponectin, which has been suggested to activate ceramide catabolism (Holland et al. 2011), as well as mediate part of FGF21 metabolic effects (Holland et al. 2013, Lin et al. 2013), although this has been recently challenged (Muise et al. 2013, Markan et al. 2014), was similar between groups (Table 1).

\section{Increased hepatic gluconeogenesis in FGF21 KO mice}

In order to understand why FGF21 KO mice had a higher basal endogenous glucose production than WT mice, we assessed different enzymes involved in gluconeogenesis. Of note, Fgf21 mRNA expression was decreased in FGF21 KO mice, according to their genotype (Fig. 5A). The expression of peroxisome proliferator activated receptor gamma coactivator 1 alpha $(P g c 1 \alpha)$ was not significantly

Published by Bioscientifica Ltd 

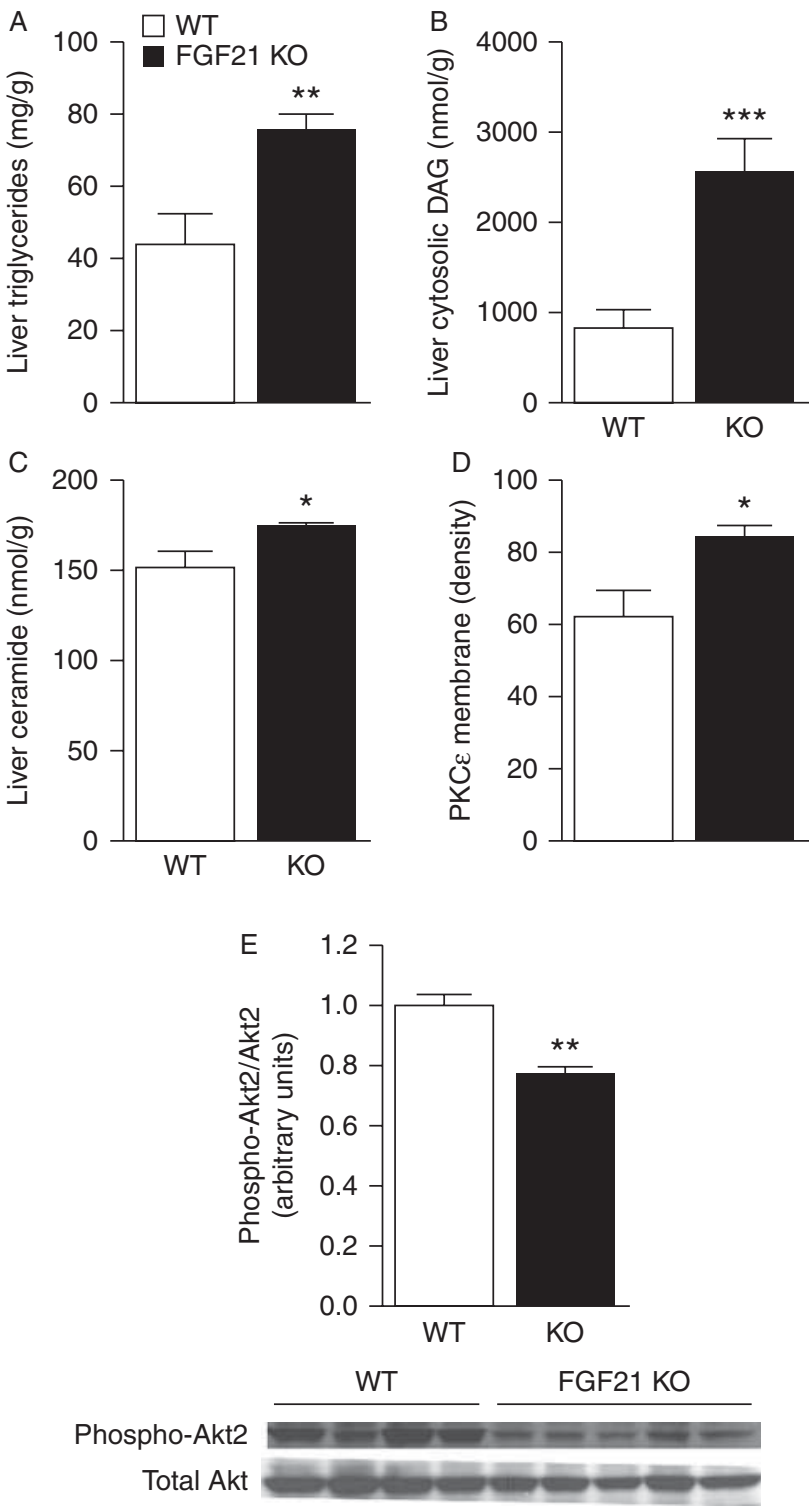

Figure 3

NAFLD and impaired hepatic insulin signaling in FGF21 KO mice. (A, B and C) Liver triglycerides (A), cytosolic DAG content (B), and ceramides content (C) were significantly increased in FGF21 KO mice ( $n=8-10 /$ group). Consequently, $\mathrm{PKC} \varepsilon$ was significantly translocated to the membrane (D) in FGF21 KO mice and insulin-stimulated Akt2 phosphorylation was decreased (E) ( $n=4-5 /$ group). ${ }^{*} P<0.05, * * P<0.01$ and $* * * P<0.001$ vs WT mice. Data are represented as mean \pm S.E.M.

altered, nor were mRNA expression of Pepck, Pc, and glucose-6-phosphatase (G6pase) (Fig. 5A). However, at the protein level, we found a significant increase in the expression of PEPCK (Fig. 5B), but not PC (Fig. 5C), in FGF21 KO mice. In association with these findings and the increased hepatic glucose production in FGF21 KO mice, plasma glucagon concentrations were more than twofold higher in FGF21 KO mice (Table 1). Finally, we found a decrease in hepatic glycogen content in FGF21 KO mice (Fig. 5D), suggesting a decrease in glycogen synthesis or an increase in glycogenolysis.

\section{Discussion}

FGF21 is rapidly gaining attention as a potent metabolic regulator that affects both glucose and lipid metabolism and reduces body weight and fat mass in numerous animal models of insulin resistance and obesity (Kharitonenkov et al. 2005, 2007, Coskun et al. 2008, Berglund et al. 2009, $\mathrm{Xu}$ et al. 2009, Camporez et al. 2013). FGF21 plasma concentrations are also correlated with insulin resistance in humans when assessed by the hyperinsulinemiceuglycemic clamp technique (Chavez et al. 2009), which represents the gold standard to evaluate insulin sensitivity. FGF21 also emerges as a biomarker of NAFLD (Li et al. 2010, Morris-Stiff \& Feldstein 2010), a highly prevalent disease in western countries. These findings of increased FGF21 levels in humans with insulin resistance actually suggest a state of FGF21 resistance. Nevertheless, these findings also suggest that giving supra-physiological doses of FGF21 could be used for the treatment of insulin resistance and other aspects of the metabolic syndrome in humans (Kliewer \& Mangelsdorf 2010).

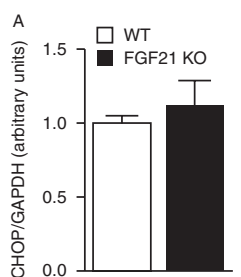

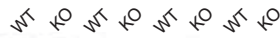
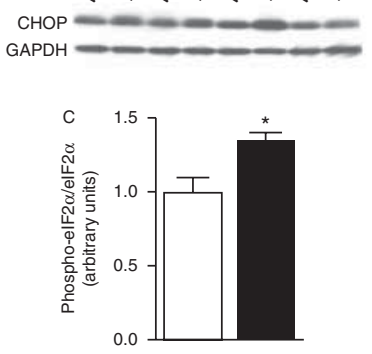

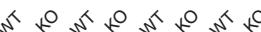

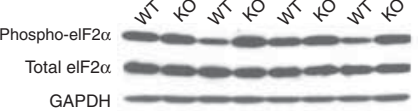

GAPDH

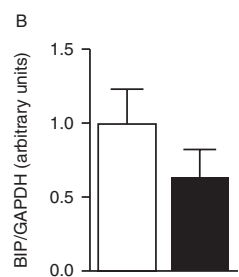

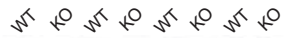

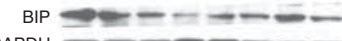

GAPDH

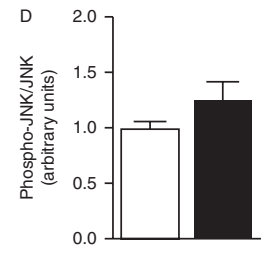

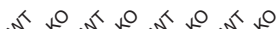
ospho-JNK $-\pi-2=$ Total JNK $=-2=-2=$ GAPDH

\section{Figure 4}

ER stress and inflammation in FGF21 KO mice. Major markers of ER stress, CHOP (A) and BIP (B) were not different between FGF21 KO and WT mice, whereas phospho-elF2 $\alpha$ (C) was significantly higher in FGF21 KO mice. Phospho-JNK (D) was not different between genotypes ( $n=4-5 /$ group). $\star P<0.05$ vs WT mice. Data are represented as mean \pm s.E.M.

Published by Bioscientifica Ltd. 

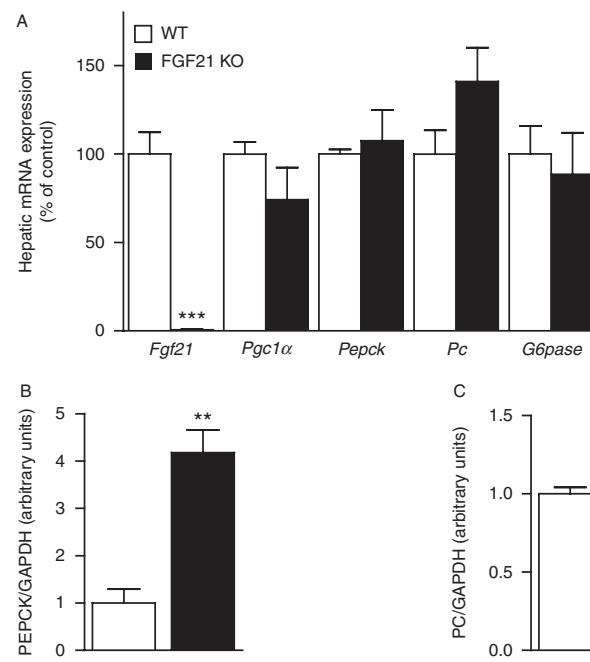

C
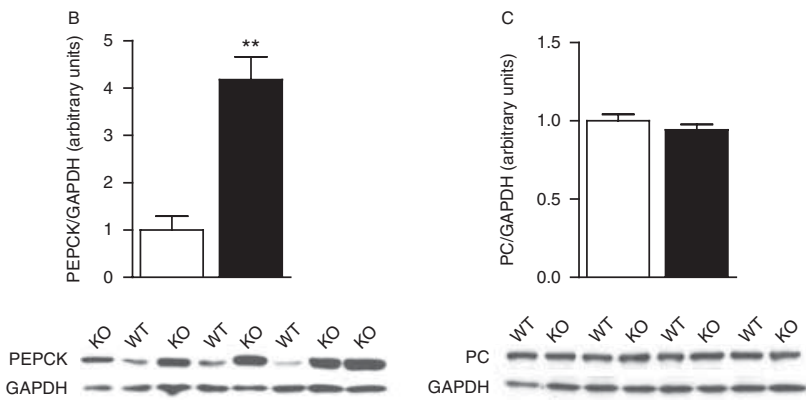
GAPDH

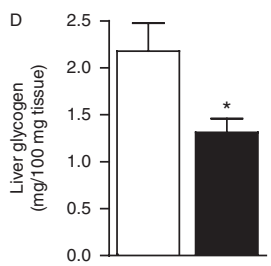

Figure 5

Increased hepatic gluconeogenesis in FGF21 KO mice. According to their genotypes, mRNA level of Fgf21 (A) were significantly decreased in FGF21 KO mice. There was no difference in the mRNA expression of Pgc1 $\alpha, P e p c k$, $P C$, and G6pase between FGF21 KO and WT mice (A) ( $n=6 /$ group). However, protein levels of PEPCK (B) were significantly increased in FGF21 KO mice, whereas there was no difference in PC protein levels (C) ( $n=4-5 / g r o u p)$. Finally, hepatic glycogen content (D) was significantly lower in FGF21 KO mice ( $n=8-9 /$ group). ${ }^{*} P<0.05$ and $* * P<0.01$ vs WT mice. Data are represented as mean \pm s.E.M.

Notably, a promising study in obese type 2 diabetic patients using FGF21 analogs during 28 days reported a trend in decreased plasma glucose levels and changes in plasma insulin levels, suggesting improved insulin sensitivity (Gaich et al. 2013).

Here, we report that mice lacking $F g / 21$ have severe hepatic insulin resistance when fed a KD compared with WT controls, when assessed by the gold-standard technique, the hyperinsulinemic-euglycemic clamp. Our results are consistent with a previous report of glucose intolerance in FGF21 KO mice, although the intraperitoneal glucose tolerance tests were not done in body weightmatched animals (Badman et al. 2009), which does not represent ideal conditions (Ayala et al. 2010) and does not distinguish hepatic vs peripheral insulin sensitivity directly. Our results are also in line with a recent study showing impaired insulin sensitivity assessed by insulin tolerance tests in mice specifically lacking $F g f 21$ in the liver (Markan et al. 2014). However, another group recently reported opposite findings, i.e., improved glucose tolerance using intraperitoneal glucose tolerance tests in FGF21 KO mice (Murata et al. 2013). The reasons for this are unclear, but could be due to a different line of mice, the different KD used, as well as the different duration of KD feeding, which was only 6 days in the study by Murata et al. (2013), therefore contrasting with previous studies (Badman et al. 2009, Jornayvaz et al. 2010), including ours. Moreover, their mice did not develop fatty liver on a KD, as opposed to our results and those of others (Badman et al. 2009, Markan et al. 2014).

Insulin resistance in our FGF21 KO mice was associated with an almost threefold increase in hepatic cytosolic DAG content leading to PKC $\varepsilon$ activation, resulting in decreased insulin signaling as shown by decreased Akt2 phosphorylation, confirming the known impairment of insulin signaling by PKC $\varepsilon$ activation (Jornayvaz \& Shulman 2012). Hepatic ceramide content was also slightly increased ( $15 \%)$ which may have also contributed to the hepatic insulin resistance observed in these mice. Also, increased basal plasma concentrations of fatty acids and impaired suppression by insulin might have played a role in the development of insulin resistance in FGF21 KO mice. This suggests that FGF21 is required to inhibit lipolysis in white adipose tissue and is consistent with previous findings (Arner et al. 2008, Hotta et al. 2009, Li et al. 2009, Murata et al. 2013). For these experiments, we decided to feed mice a $\mathrm{KD}$ because we previously reported that such a diet induces hepatic insulin resistance in WT mice with high plasma levels of FGF21 (Jornayvaz et al. 2010), consistent with the elevation of FGF21 seen in insulin resistance in humans (Chavez et al. 2009) and mice (Fisher et al. 2010, Jornayvaz et al. 2010). As WT mice are insulin resistant when fed a $\mathrm{KD}$, we now show that mice lacking $F g f 21$ are even more insulin resistant when fed the same diet. However, these studies raise the question as to whether the increase in FGF21 on a KD contributes to the development of insulin resistance or if it is a counter regulatory mechanism to promote the use of lipids during this challenge. Our experiments test this directly and show that FGF21 provides some level of protection against insulin resistance. However, the increase in FGF21, whether mice are fed a KD (Jornayvaz et al. 2010) or a high-fat diet (Fisher et al. 2010), is insufficient to protect against insulin resistance. However, KD has been shown to increase FGF21 levels because FGF21 is an endocrine signal of protein restriction (Laeger et al. 2014). KD can therefore

Published by Bioscientifica Ltd 
increase FGF21 independently of insulin resistance. The increase in hepatic lipid content in FGF21 KO mice is consistent with a role of FGF21 in the regulation of hepatic lipid metabolism (Badman et al. 2007). Specifically, mice lacking $F g f 21$ fed a KD are known to have an increase in hepatic protein levels of sterol regulatory binding protein element 1c (SREBP1c; Badman et al. 2009), a master regulator of lipid synthesis.

Interestingly, when fed a KD, FGF21 KO mice had a decrease in energy expenditure, and this is a likely explanation of why their body weight increases with age. These results confirm data from previous reports where FGF21 was shown to act as a regulator of energy metabolism (Coskun et al. 2008, Xu et al. 2009, Camporez et al. 2013). The effect of FGF21 on energy expenditure is likely to be direct, as we found no difference in locomotor activity, food consumption, or respiratory quotient. Moreover, we found that the level of UCP1, the main protein dissipating heat at the level of the brown adipose tissue, was significantly reduced in FGF21 KO mice. However, by surgically removing brown adipose tissue, we previously showed that FGF21 can also increase energy expenditure independently of brown adipose tissue, notably in white adipose tissue, suggesting that FGF21 can increase energy expenditure in other organs (Camporez et al. 2013).

We also found evidence of a potential role of FGF21 on ER stress as evidenced by an increase in phospho-eIF $2 \alpha$. Phospho-eIF $2 \alpha$, an important marker of ER stress, was significantly increased in FGF21 KO mice. It is not clear why this marker of ER stress of the PERK arm was increased, whereas CHOP, another ER stress marker from the PERK arm, was not. However, this elevation may be secondary to higher fat content in the liver of FGF21 KO mice compared to WT mice. Moreover, this corroborates findings in obese non-diabetic patients with NAFLD (Kumashiro et al. 2011). Finally, adiponectin, which is thought to mediate insulin sensitivity by activating ceramidase activity (Holland et al. 2011) and has recently been shown to mediate part of FGF21 metabolic actions (Holland et al. 2013, Lin et al. 2013), was not different between groups and was therefore unlikely to play a major role in the hepatic insulin resistance seen in mice lacking $F g f 21$. These findings are therefore in line with recent studies suggesting that other factors than adiponectin mediate FGF21 effects (Muise et al. 2013, Markan et al. 2014).

An important finding here was that mice lacking Fgf 21 had an increase in endogenous glucose production, which can be the result of both increased gluconeogenesis and/or glycogenolysis. We found no difference in the mRNA expression of major gluconeogenic enzymes, but found a significant increase in PEPCK protein level, providing evidence for increased gluconeogenesis. It is not surprising that mRNA levels were not altered, as it has been shown that increased transcriptional expression of Pepck does not account for increased gluconeogenesis and fasting hyperglycemia in patients with type 2 diabetes. Indeed, hepatic expression of Pepck was not different between insulin sensitive and type 2 diabetic subjects (Samuel et al. 2009). Interestingly, a study reported in vitro in Hepa1-6 hepatocytes that downregulation of $F g f 21$ increases Pepck expression, whereas upregulation of $F g f 21$ decreases Pepck (Li et al. 2012). The latter finding was further confirmed in the rat H4IIE hepatoma cell line (Kong et al. 2013). Therefore, other mechanisms associated with lack of $F \& f 21$ that have yet to be unraveled potentially affect the posttranscriptional modification of PEPCK, which suggests that FGF21 plays an important role in gluconeogenesis. We also report decreased hepatic glycogen content in FGF21 KO mice, which could reflect decreased glycogen synthesis or increased glycogenolysis. The latter would be more likely, based on the increased endogenous glucose production evidenced in FGF21 KO mice, and is further corroborated by the higher plasma glucagon levels in these mice, although these findings remain associative. This increase in plasma glucagon levels contrasts with previous reports (Badman et al. 2009, Potthoff et al. 2009, Murata et al. 2013), but might reflect the different diet used and the duration of the diet. Also, glucagon is rapidly destroyed in plasma; we therefore used aprotinin during blood collection to avoid degradation of the hormone. However, our results mirror findings in mice overexpressing Fgf21, where plasma glucagon levels were significantly lower in females and tended to be lower in males (Kharitonenkov et al. 2005). This increase in glucagon might be a compensatory mechanism to increase FGF21 concentrations, as recent findings reported that glucagon increases FGF21 levels (Arafat et al. 2013), further mediating glucagon actions (Habegger et al. 2013), but these considerations remain speculative, as we have no direct evidence. Nevertheless, glucagon levels have been reported to be lowered after FGF21 injections in $o b /+$ (Berglund et al. 2009) and $d b / d b$ mice (Mu et al. 2012), as well as in diabetic monkeys (Kharitonenkov et al. 2007) and in isolated rat pancreatic islets (Kharitonenkov et al. 2005). Finally, the increased basal plasma insulin concentrations in FGF21 KO mice may be secondary to the increased endogenous glucose production.

In conclusion, the present study demonstrates that mice specifically lacking $F g f 21$ develop hepatic insulin

Published by Bioscientifica Ltd. 
resistance when fed a KD, thereby involving FGF21 as a regulator of hepatic insulin resistance. In this case, hepatic insulin resistance can be attributed to an increase in hepatic DAG content, leading to PKCe activation and subsequent impaired insulin signaling. Taken together, these findings support the hypothesis that FGF21 plays a key role in NAFLD-associated hepatic insulin resistance and provide new support of FGF21 as a pharmacological candidate in insulin resistance and associated diseases.

\section{Supplementary data}

This is linked to the online version of the paper at http://dx.doi.org/10.1530/ JOE-15-0136.

\section{Declaration of interest}

The authors declare that there is no conflict of interest that could be perceived as prejudicing the impartiality of the research reported.

\section{Funding}

F R J was funded by a grant from the Swiss National Science Foundation/Swiss Foundation for Grants in Biology and Medicine (PASMP3_132563) and the Helmut Horten Foundation.

\section{Author contribution statement}

J P G C designed experiments, researched data, and wrote manuscript. $M$ A researched data, contributed to discussion, and reviewed/edited manuscript. D Z researched data. M K researched data. $V \mathrm{~T} S$ contributed to discussion and reviewed/edited manuscript. M J J designed experiments, researched data, contributed to discussion, and reviewed/edited manuscript. F R J designed experiments, researched data, reviewed/edited manuscript, contributed to discussion, and wrote manuscript. All authors approved the final version. $\mathrm{F} \mathrm{R} \mathrm{J} \mathrm{is} \mathrm{the} \mathrm{guarantor} \mathrm{of} \mathrm{this} \mathrm{work.}$

\section{Acknowledgements}

We thank Steven A Kliewer, David J Mangelsdorf, Angie L Bookout, and Yuan Zhang at UT Southwestern for FGF21 KO mice and expert technical assistance. We also thank Xian-man Zhang, Blas Guigni, Julie Serr, Xiaoxian $\mathrm{Ma}$, and Aida Groszman for expert technical assistance at Yale.

\section{References}

Angulo P 2002 Nonalcoholic fatty liver disease. New England Journal of Medicine 346 1221-1231. (doi:10.1056/NEJMra011775)

Arafat AM, Kaczmarek P, Skrzypski M, Pruszynska-Oszmalek E, Kolodziejski P, Szczepankiewicz D, Sassek M, Wojciechowicz T, Wiedenmann B, Pfeiffer AF et al. 2013 Glucagon increases circulating fibroblast growth factor 21 independently of endogenous insulin levels: a novel mechanism of glucagon-stimulated lipolysis? Diabetologia 56 588-597. (doi:10.1007/s00125-012-2803-y)

Arner P, Pettersson A, Mitchell PJ, Dunbar JD, Kharitonenkov A \& Ryden M 2008 FGF21 attenuates lipolysis in human adipocytes - a possible link to improved insulin sensitivity. FEBS Letters 582 1725-1730. (doi:10.1016/j.febslet.2008.04.038)

Asrih M \& Jornayvaz FR 2013 Inflammation as a potential link between nonalcoholic fatty liver disease and insulin resistance. Journal of Endocrinology 218 R25-R36. (doi:10.1530/JOE-13-0201)

Asrih M \& Jornayvaz FR 2015 Metabolic syndrome and nonalcoholic fatty liver disease: is insulin resistance the link? Molecular and Cellular Endocrinology [in press]. (doi:10.1016/j.mce.2015.02.018)

Asrih M, Altirriba J, Rohner-Jeanrenaud F \& Jornayvaz FR 2015 Ketogenic diet impairs FGF21 signaling and promotes differential inflammatory responses in the liver and white adipose tissue. PLOS ONE 10 e0126364. (doi:10.1371/journal.pone.0126364)

Ayala JE, Samuel VT, Morton GJ, Obici S, Croniger CM, Shulman GI, Wasserman DH \& McGuinness OP 2010 Standard operating procedures for describing and performing metabolic tests of glucose homeostasis in mice. Disease Models \& Mechanisms 3 525-534. (doi:10.1242/dmm. 006239)

Badman MK, Pissios P, Kennedy AR, Koukos G, Flier JS \& Maratos-Flier E 2007 Hepatic fibroblast growth factor 21 is regulated by PPAR $\alpha$ and is a key mediator of hepatic lipid metabolism in ketotic states. Cell Metabolism 5 426-437. (doi:10.1016/j.cmet.2007.05.002)

Badman MK, Koester A, Flier JS, Kharitonenkov A \& Maratos-Flier E 2009 Fibroblast growth factor 21-deficient mice demonstrate impaired adaptation to ketosis. Endocrinology 150 4931-4940. (doi:10.1210/en. 2009-0532)

Berglund ED, Li CY, Bina HA, Lynes SE, Michael MD, Shanafelt AB, Kharitonenkov A \& Wasserman DH 2009 Fibroblast growth factor 21 controls glycemia via regulation of hepatic glucose flux and insulin sensitivity. Endocrinology 150 4084-4093. (doi:10.1210/en.2009-0221)

Birkenfeld AL, Lee HY, Guebre-Egziabher F, Alves TC, Jurczak MJ, Jornayvaz FR, Zhang D, Hsiao JJ, Martin-Montalvo A, Fischer-Rosinsky A et al. 2011 Deletion of the mammalian INDY homolog mimics aspects of dietary restriction and protects against adiposity and insulin resistance in mice. Cell Metabolism 14 184-195. (doi:10.1016/j.cmet. 2011.06.009)

Bligh EG \& Dyer WJ 1959 A rapid method of total lipid extraction and purification. Canadian Journal of Biochemistry and Physiology $\mathbf{3 7}$ 911-917. (doi:10.1139/o59-099)

Camporez JP, Jornayvaz FR, Petersen MC, Pesta D, Guigni BA, Serr J, Zhang D, Kahn M, Samuel VT, Jurczak MJ et al. 2013 Cellular mechanisms by which FGF21 improves insulin sensitivity in male mice. Endocrinology 154 3099-3109. (doi:10.1210/en.2013-1191)

Chavez AO, Molina-Carrion M, Abdul-Ghani MA, Folli F, Defronzo RA \& Tripathy D 2009 Circulating fibroblast growth factor-21 is elevated in impaired glucose tolerance and type 2 diabetes and correlates with muscle and hepatic insulin resistance. Diabetes Care 32 1542-1546. (doi:10.2337/dc09-0684)

Choi CS, Savage DB, Kulkarni A, Yu XX, Liu ZX, Morino K, Kim S, Distefano A, Samuel VT, Neschen S et al. 2007 Suppression of diacylglycerol acyltransferase-2 (DGAT2), but not DGAT1, with antisense oligonucleotides reverses diet-induced hepatic steatosis and insulin resistance. Journal of Biological Chemistry 282 22678-22688. (doi:10.1074/jbc.M704213200)

Coskun T, Bina HA, Schneider MA, Dunbar JD, Hu CC, Chen Y, Moller DE \& Kharitonenkov A 2008 Fibroblast growth factor 21 corrects obesity in mice. Endocrinology 149 6018-6027. (doi:10.1210/en.2008-0816)

Ding X, Boney-Montoya J, Owen BM, Bookout AL, Coate KC, Mangelsdorf DJ \& Kliewer SA $2012 \beta$ Klotho is required for fibroblast growth factor 21 effects on growth and metabolism. Cell Metabolism 16 387-393. (doi:10.1016/j.cmet.2012.08.002)

Dushay J, Chui PC, Gopalakrishnan GS, Varela-Rey M, Crawley M, Fisher FM, Badman MK, Martinez-Chantar ML \& Maratos-Flier E 2010 Increased fibroblast growth factor 21 in obesity and nonalcoholic fatty liver disease. Gastroenterology 139 456-463. (doi:10.1053/j.gastro.2010. 04.054) 
Fabbrini E, Sullivan S \& Klein S 2010 Obesity and nonalcoholic fatty liver disease: biochemical, metabolic, and clinical implications. Hepatology 51 679-689. (doi:10.1002/hep.23280)

Finucane MM, Stevens GA, Cowan MJ, Danaei G, Lin JK, Paciorek CJ, Singh GM, Gutierrez HR, Lu Y, Bahalim AN et al. 2011 National, regional, and global trends in body-mass index since 1980: systematic analysis of health examination surveys and epidemiological studies with 960 country-years and 9.1 million participants. Lancet 377 557-567. (doi:10.1016/S0140-6736(10)62037-5)

Fisher FM, Chui PC, Antonellis PJ, Bina HA, Kharitonenkov A, Flier JS \& Maratos-Flier E 2010 Obesity is a fibroblast growth factor 21 (FGF21)resistant state. Diabetes 59 2781-2789. (doi:10.2337/db10-0193)

Fisher FM, Kleiner S, Douris N, Fox EC, Mepani RJ, Verdeguer F, Wu J, Kharitonenkov A, Flier JS, Maratos-Flier E et al. 2012 FGF21 regulates PGC- $1 \alpha$ and browning of white adipose tissues in adaptive thermogenesis. Genes and Development 26 271-281. (doi:10.1101/gad. 177857.111)

Flegal KM, Carroll MD, Ogden CL \& Curtin LR 2010 Prevalence and trends in obesity among US adults, 1999-2008. Journal of the American Medical Association 303 235-241. (doi:10.1001/jama.2009.2014)

Gaich G, Chien JY, Fu H, Glass LC, Deeg MA, Holland WL, Kharitonenkov A, Bumol T, Schilske HK \& Moller DE 2013 The effects of LY2405319, an FGF21 analog, in obese human subjects with type 2 diabetes. Cell Metabolism 18 333-340. (doi:10.1016/j.cmet.2013.08.005)

Habegger KM, Stemmer K, Cheng C, Muller TD, Heppner KM, Ottaway N, Holland J, Hembree JL, Smiley D, Gelfanov V et al. 2013 Fibroblast growth factor 21 mediates specific glucagon actions. Diabetes 62 1453-1463. (doi:10.2337/db12-1116)

Holland WL, Brozinick JT, Wang LP, Hawkins ED, Sargent KM, Liu Y, Narra K, Hoehn KL, Knotts TA, Siesky A et al. 2007 Inhibition of ceramide synthesis ameliorates glucocorticoid-, saturated-fat-, and obesity-induced insulin resistance. Cell Metabolism 5 167-179. (doi:10.1016/j.cmet.2007.01.002)

Holland WL, Miller RA, Wang ZV, Sun K, Barth BM, Bui HH, Davis KE, Bikman BT, Halberg N, Rutkowski JM et al. 2011 Receptor-mediated activation of ceramidase activity initiates the pleiotropic actions of adiponectin. Nature Medicine 17 55-63. (doi:10.1038/nm.2277)

Holland WL, Adams AC, Brozinick JT, Bui HH, Miyauchi Y, Kusminski CM, Bauer SM, Wade M, Singhal E, Cheng CC et al. 2013 An FGF21adiponectin-ceramide axis controls energy expenditure and insulin action in mice. Cell Metabolism 17 790-797. (doi:10.1016/j.cmet.2013. 03.019)

Hotamisligil GS 2006 Inflammation and metabolic disorders. Nature $\mathbf{4 4 4}$ 860-867. (doi:10.1038/nature05485)

Hotamisligil GS 2010 Endoplasmic reticulum stress and the inflammatory basis of metabolic disease. Cell 140 900-917. (doi:10.1016/j.cell.2010. 02.034)

Hotta Y, Nakamura H, Konishi M, Murata Y, Takagi H, Matsumura S, Inoue K, Fushiki T \& Itoh N 2009 Fibroblast growth factor 21 regulates lipolysis in white adipose tissue but is not required for ketogenesis and triglyceride clearance in liver. Endocrinology $1504625-4633$. (doi:10.1210/en.2009-0119)

Jornayvaz FR \& Shulman GI 2012 Diacylglycerol activation of protein kinase $\mathrm{C} \varepsilon$ and hepatic insulin resistance. Cell Metabolism 15 574-584. (doi:10.1016/j.cmet.2012.03.005)

Jornayvaz FR, Jurczak MJ, Lee HY, Birkenfeld AL, Frederick DW, Zhang D, Zhang XM, Samuel VT \& Shulman GI 2010 A high-fat, ketogenic diet causes hepatic insulin resistance in mice, despite increasing energy expenditure and preventing weight gain. American Journal of Physiology. Endocrinology and Metabolism 299 E808-E815. (doi:10.1152/ajpendo. 00361.2010)

Jornayvaz FR, Birkenfeld AL, Jurczak MJ, Kanda S, Guigni BA, Jiang DC, Zhang D, Lee HY, Samuel VT \& Shulman GI 2011 Hepatic insulin resistance in mice with hepatic overexpression of diacylglycerol acyltransferase 2. PNAS $\mathbf{1 0 8}$ 5748-5752. (doi:10.1073/pnas. 1103451108)
Jornayvaz FR, Lee HY, Jurczak MJ, Alves TC, Guebre-Egziabher F, Guigni BA, Zhang D, Samuel VT, Silva JE \& Shulman GI 2012 Thyroid hormone receptor- $\alpha$ gene knockout mice are protected from diet-induced hepatic insulin resistance. Endocrinology 153 583-591. (doi:10.1210/en.20111793)

Kharitonenkov A \& Larsen P 2011 FGF21 reloaded: challenges of a rapidly growing field. Trends in Endocrinology and Metabolism 22 81-86. (doi:10.1016/j.tem.2010.11.003)

Kharitonenkov A, Shiyanova TL, Koester A, Ford AM, Micanovic R, Galbreath EJ, Sandusky GE, Hammond LJ, Moyers JS, Owens RA et al. 2005 FGF-21 as a novel metabolic regulator. Journal of Clinical Investigation 115 1627-1635. (doi:10.1172/JCI23606)

Kharitonenkov A, Wroblewski VJ, Koester A, Chen YF, Clutinger CK, Tigno XT, Hansen BC, Shanafelt AB \& Etgen GJ 2007 The metabolic state of diabetic monkeys is regulated by fibroblast growth factor- 21 . Endocrinology 148 774-781. (doi:10.1210/en.2006-1168)

Kliewer SA \& Mangelsdorf DJ 2010 Fibroblast growth factor 21: from pharmacology to physiology. American Journal of Clinical Nutrition 91 254S-257S. (doi:10.3945/ajcn.2009.28449B)

Kong LJ, Feng W, Wright M, Chen Y, Dallas-yang Q, Zhou YP \& Berger JP 2013 FGF21 suppresses hepatic glucose production through the activation of atypical protein kinase $\mathrm{Cl} / \lambda$. European Journal of Pharmacology 702 302-308. (doi:10.1016/j.ejphar.2012.11.065)

Kumashiro N, Erion DM, Zhang D, Kahn M, Beddow SA, Chu X, Still CD, Gerhard GS, Han X, Dziura J et al. 2011 Cellular mechanism of insulin resistance in nonalcoholic fatty liver disease. PNAS 108 16381-16385. (doi:10.1073/pnas.1113359108)

Laeger T, Henagan TM, Albarado DC, Redman LM, Bray GA, Noland RC, Munzberg H, Hutson SM, Gettys TW, Schwartz MW et al. 2014 FGF21 is an endocrine signal of protein restriction. Journal of Clinical Investigation 124 3913-3922. (doi:10.1172/JCI74915)

Li X, Ge H, Weiszmann J, Hecht R, Li YS, Veniant MM, Xu J, Wu X, Lindberg R \& Li Y 2009 Inhibition of lipolysis may contribute to the acute regulation of plasma FFA and glucose by FGF21 in ob/ob mice. FEBS Letters 583 3230-3234. (doi:10.1016/j.febslet.2009.09.012)

Li H, Fang Q, Gao F, Fan J, Zhou J, Wang X, Zhang H, Pan X, Bao Y, Xiang K et al. 2010 Fibroblast growth factor 21 levels are increased in nonalcoholic fatty liver disease patients and are correlated with hepatic triglyceride. Journal of Hepatology 53 934-940. (doi:10.1016/j.jhep. 2010.05.018)

Li K, Li L, Yang M, Liu H, Boden G \& Yang G 2012 The effects of fibroblast growth factor-21 knockdown and over-expression on its signaling pathway and glucose-lipid metabolism in vitro. Molecular and Cellular Endocrinology 348 21-26. (doi:10.1016/j.mce.2011.07.026)

Lin Z, Tian H, Lam KS, Lin S, Hoo RC, Konishi M, Itoh N, Wang Y, Bornstein SR, Xu A et al. 2013 Adiponectin mediates the metabolic effects of FGF21 on glucose homeostasis and insulin sensitivity in mice. Cell Metabolism 17 779-789. (doi:10.1016/j.cmet.2013.04.005)

Markan KR, Naber MC, Ameka MK, Anderegg MD, Mangelsdorf DJ, Kliewer SA, Mohammadi M \& Potthoff MJ 2014 Circulating FGF21 is liver derived and enhances glucose uptake during refeeding and overfeeding. Diabetes 63 4057-4063. (doi:10.2337/db14-0595)

Morris-Stiff G \& Feldstein AE 2010 Fibroblast growth factor 21 as a biomarker for NAFLD: integrating pathobiology into clinical practice. Journal of Hepatology 53 795-796. (doi:10.1016/j.jhep.2010.07.003)

Mu J, Pinkstaff J, Li Z, Skidmore L, Li N, Myler H, Dallas-Yang Q, Putnam AM, Yao J, Bussell S et al. 2012 FGF21 analogs of sustained action enabled by orthogonal biosynthesis demonstrate enhanced antidiabetic pharmacology in rodents. Diabetes $61505-512$. (doi:10.2337/db11-0838)

Muise ES, Souza S, Chi A, Tan Y, Zhao X, Liu F, Dallas-Yang Q, Wu M, Sarr T, Zhu L et al. 2013 Downstream signaling pathways in mouse adipose tissues following acute in vivo administration of fibroblast growth factor 21. PLoS ONE 8 e73011. (doi:10.1371/journal.pone.0073011)

Murata Y, Nishio K, Mochiyama T, Konishi M, Shimada M, Ohta H \& Itoh N 2013 Fgf21 impairs adipocyte insulin sensitivity in mice fed a

Published by Bioscientifica Ltd. 
low-carbohydrate, high-fat ketogenic diet. PLoS ONE 8 e69330. (doi:10.1371/journal.pone.0069330)

Ozcan U, Cao Q, Yilmaz E, Lee AH, Iwakoshi NN, Ozdelen E, Tuncman G, Gorgun C, Glimcher LH \& Hotamisligil GS 2004 Endoplasmic reticulum stress links obesity, insulin action, and type 2 diabetes. Science 306 457-461. (doi:10.1126/science.1103160)

Pfaffl MW 2001 A new mathematical model for relative quantification in real-time RT-PCR. Nucleic Acids Research 29 e45. (doi:10.1093/nar/29. 9.e45)

Potthoff MJ, Inagaki T, Satapati S, Ding X, He T, Goetz R, Mohammadi M, Finck BN, Mangelsdorf DJ, Kliewer SA et al. 2009 FGF21 induces PGC-1 $\alpha$ and regulates carbohydrate and fatty acid metabolism during the adaptive starvation response. PNAS 106 10853-10858. (doi:10.1073/ pnas.0904187106)

Samuel VT, Liu ZX, Wang A, Beddow SA, Geisler JG, Kahn M, Zhang XM, Monia BP, Bhanot S \& Shulman GI 2007 Inhibition of protein kinase C $\varepsilon$ prevents hepatic insulin resistance in nonalcoholic fatty liver disease. Journal of Clinical Investigation 117 739-745. (doi:10.1172/JCI30400)

Samuel VT, Beddow SA, Iwasaki T, Zhang XM, Chu X, Still CD, Gerhard GS \& Shulman GI 2009 Fasting hyperglycemia is not associated with increased expression of PEPCK or G6Pc in patients with type 2 diabetes. PNAS 106 12121-12126. (doi:10.1073/pnas.0812547106)

Samuel VT, Petersen KF \& Shulman GI 2010 Lipid-induced insulin resistance: unravelling the mechanism. Lancet 375 2267-2277. (doi:10.1016/S0140-6736(10)60408-4)
Schaap FG, Kremer AE, Lamers WH, Jansen PL \& Gaemers IC 2013 Fibroblast growth factor 21 is induced by endoplasmic reticulum stress. Biochimie 95 692-699. (doi:10.1016/j.biochi.2012.10.019)

Shulman GI 2000 Cellular mechanisms of insulin resistance. Journal of Clinical Investigation 106 171-176. (doi:10.1172/JCI10583)

Wang Y, Solt LA \& Burris TP 2010 Regulation of FGF21 expression and secretion by retinoic acid receptor-related orphan receptor $\alpha$. Journal of Biological Chemistry 285 15668-15673. (doi:10.1074/jbc. M110.102160)

Williams CD, Stengel J, Asike MI, Torres DM, Shaw J, Contreras M, Landt CL \& Harrison SA 2011 Prevalence of nonalcoholic fatty liver disease and nonalcoholic steatohepatitis among a largely middle-aged population utilizing ultrasound and liver biopsy: a prospective study. Gastroenterology 140 124-131. (doi:10.1053/j.gastro. 2010.09.038)

Xu J, Lloyd DJ, Hale C, Stanislaus S, Chen M, Sivits G, Vonderfecht S, Hecht R, Li YS, Lindberg RA et al. 2009 Fibroblast growth factor 21 reverses hepatic steatosis, increases energy expenditure, and improves insulin sensitivity in diet-induced obese mice. Diabetes 58 250-259. (doi:10.2337/db08-0392)

Yu C, Chen Y, Cline GW, Zhang D, Zong H, Wang Y, Bergeron R, Kim JK, Cushman SW, Cooney GJ et al. 2002 Mechanism by which fatty acids inhibit insulin activation of insulin receptor substrate-1 (IRS-1)associated phosphatidylinositol 3-kinase activity in muscle. Journal of Biological Chemistry 277 50230-50236. (doi:10.1074/jbc.M200958200)

Received in final form 26 June 2015

Accepted 21 July 2015

Accepted Preprint published online 22 July 2015
(C) 2015 Society for Endocrinology Printed in Great Britain 